\title{
DAMPAK PANDEMI COVID-19 TERHADAP SEKTOR RIIL: TELAAH, HARAPAN DAN PENENTUAN ARAH KEBIJAKAN SUSTAINABLE DEVELOPMENT GOALS (SDGs) DAN ZISWAF
}

\author{
Muhibbul Zibbri; Habibah Awwaliah; Lailussoma; Muhamad Fauzin Nur \\ Universitas Islam Negeri Sunan Ampel Surabaya \\ e-mail: muhibbulzibbri@mail.com; habibahawaalia37@gmail.com; \\ lailussoma20@gmail.com; fauzinmuhammad@gmail.com
}

\begin{abstract}
Covid-19 is a virus that spreads very rapidly and has a clear impact on the areas of human life, such as health, social, economic, and religious perspective. The real impacts occurred in the economic sector are the declined economy due to the physical distancing policy for the community to do activities and the decreased public consumption which resulted in stagnant circulation of money. This is in accordance with the theory of the flow concept, money (property) must continue to flow to ensure that the economy is alive and integrated with one another, so that there is a confluence of economic circulation between the excess and the needy, and vice versa. Objectives that identify and provide recommendations that seek to support the SDG, especially the values that end all forms of society and inequality in communities affected by covid-19. This article uses descriptive qualitative methods using written sources such as the latest news, books, and research journals, as well as interview results that are relevant to the theme raised. The results of this study state that philanthropy can be an effective medium and means of supporting distribution stimulus while at the same time overcoming the impact of the spread of covid-19. This effort is also related to the application of SDG values which are oriented towards poverty alleviation and reduction of victims of malnutrition in the present or future. The suggestion that can be delivered is the cooperation between the community and the government which is assisted by the improvement of the ZISWAF Institution's performance. It is hoped that it can optimize the realization of philanthropic funds to reduce the economic burden of victims while also applying the value of the Sustainable Development Goals (SDG).
\end{abstract}

Keywords: covid-19, islamic philanthropy, Sustainable Development Goals

\section{Pendahuluan}

Penghujung tahun 2019, dunia digemparkan oleh adanya sebuah virus baru yang pertama kali dilaporkan menyebar di kota Wuhan Tiongkok. ${ }^{1}$ Sebuah virus baru yang menyerang saluran pernapasan manusia dan berakibat pada kematian sebagai akibat terparah. ${ }^{2}$ Di Indonesia sendiri, awal terkonfirmasi positif covid 19 pada bulan Maret 2020 di mana terdapat dua orang pertama positif setelah melakukan kontak langsung dengan warga negara asing. Berdasarkan data yang dirilis oleh Gugus Tugas Percepatan Penanganan Covid-19 sejak awal dikonfirmasinya virus ini hingga per 13 Januari 2021 jumlah kasus terkonfirmasi

\footnotetext{
${ }^{1}$ Danny Ibarra Vega, "Lockdown, One, Two, None, or Smart. Modeling Containing Covid-19 Infection. A Conceptual Model", Science of The Total Environment, Volume 16, Nomor 2 (2020), 93.

${ }^{2}$ Andrew Atkeson, "What Will Be the Economic Impact of Covid-19 in the US? Rough Estimates of Disease Scenarios," NBER Working Paper Series (2020), 25.
} 
positif di Indonesia adalah sebanyak 858.043 di mana 703.464 terkonfirmasi sembuh, dan 24.951 terkonfirmasi meninggal. Sedangkan pada tingkat dunia berdasarkan data yang dirilis oleh WHO jumlah pasien terkonfirmasi positif covid-19 adalah 90.054.813 yang berasal dari 223 negara dan 1.945.610 terkonfirmasi meninggal.

Adanya penyebaran virus covid-19 berdampak pada perubahan perilaku dan kebiasaan masyarakat di seluruh dunia. ${ }^{3}$ Hal tersebut berdampak pada sektor-sektor yang meliputi segala bidang kehidupan manusia, seperti dalam hal bersosialisasi, efektivitas aktivitas keseharian, kegiatan keagamaan, politik, ekonomi dan aspek lainnya yang berkaitan. ${ }^{4}$ Selain pada kebiasaan juga terdapat istilah-istilah baru yang muncul, seperti work from home, physical distancing, social distancing, lockdown, PSBB (Pembatasan Sosial Skala Besar), dan new normal. Hal ini bukan hanya sekedar istilah namun juga pada praktiknya di lapangan di mana salah satunya adalah social distancing yang merupakan pembatasan aktivitas manusia dalam melaksanakan aktivitas sehari-hari termasuk bekerja dan beribadah. Hal ini diberlakukan sebagai upaya untuk melakukan pencegahan dan pengurangan terhadap penyebaran covid-19. Namun sebagai dampaknya banyak sekali masyarakat yang terkena imbas dari adanya social distancing, antara lain pemutusan hubungan kerja (PHK) dan jauh lebih berat adalah kegiatan ekonomi tidak berjalan seperti biasanya, seperti penurunan produksi, distribusi yang tersendat juga penurunan daya beli dan konsumsi masyarakat serta adanya ancaman pertumbuhan ekonomi yang terus menurun atau dengan opsi terburuknya akan terjadi resesi.

Pasien positif covid-19 terus bertambah setiap harinya namun adanya PSBB yang diterapkan di Indonesia dirasa berdampak serius pada perekonomian. ${ }^{5}$ Kondisi perekonomian yang semakin memburuk dan adanya ancaman terjadi resesi ekonomi membuat pemerintah menerapkan kebijakan baru, yaitu new normal. ${ }^{6}$ Sebuah kebijakan baru yang membolehkan masyarakat beraktivitas seperti biasa terutama di wilayah yang sudah berstatus hijau, kebijakan ini diberlakukan baik bagi para pelaku bisnis, pegawai negeri, kegiatan pendidikan, keagamaan dan perekonomian dengan ketentuan-ketentuan atau protokol kesehatan yang digunakan untuk menghindari terjadinya gelombang kedua penyebaran covid-19 di Indonesia.

Dampak lain dari adanya covid-19 adalah peningkatan jumlah angka kemiskinan. Sebagai dampak dari matinya kegiatan masyarakat yang tidak dapat bekerja seperti biasa dan tidak dapat memenuhi kebutuhan sehari-hari berimbas pada bertambahnya digit angka kemiskinan di Indonesia. Hal ini jelas tidak sesuai dengan tujuan dari Sustainable Development Goals (SDGs) terkait dengan tujuan pertamanya, yaitu mengakhiri kemiskinan dalam segala bentuk, dukungan terhadap pertumbuhan ekonomi yang inklusif dan berkelanjutan, tenaga kerja penuh dan produktif dan pekerjaan yang layak bagi semua, serta untuk mengurangi ketimpangan di dalam dan antar negara. ${ }^{7}$ Dengan kata lain adanya pandemi

\footnotetext{
${ }^{3}$ Nuno Fernandes, "Economic Effects of Corona Virus Outbreak (Covid-19) on the World Economy", SSRN Electronic Journal, Volume 13, Nomor 1 (2020), 0-29.

${ }^{4}$ Priyono Budi Santoso, dkk, "Studi Eksploratif Dampak Pandemi Covid-19 Terhadap Proses Pembelajaran Online di Sekolah Dasar", Journal of Education, Psycology, and Counseling, Volume 2, Nomor 1 (2020), 45.

5 Irham Zaki, dkk, "Implementation of Islamic Entrepreneurial Culture in Islamic Boarding Schools", International Journal of Innovation, Creativity and Change, Volume 11, Nomor 11 (2020), 452.

${ }^{6}$ Ana Toni Roby Candra Yudha, dkk, "The Synergy Model for Strengthening the Productivity of Indonesian Halal Industry", al-Uqud, Volume 4, Nomor 2 (2020), 186-199.

7 Mohammad Abdullah, "Waqf, Sustainable Development Goals (SDGs) and Maqasid Al-Shariah", International Journal of Social Economics, Volume 45, Nomor 1 (2018), 158-172.
} 
covid-19 berdampak pada tidak berjalannya tujuan dari SDGs dan menjadi tugas rumah bagi pemerintah untuk menciptakan suatua kebijakan yang diharapkan oleh masyarakat secara umum dan sesuai dengan kondisi yang saat ini terjadi di tengah masyarakat kita.

SDGs dengan keseluruhan tujuannya berusaha meningkatkan taraf kehidupan manusia di seluruh muka bumi. ${ }^{8}$ Tanpa adanya penyebaran covid-19 tujuan-tujuan dari SDGs sudah sulit untuk tercapai ditambah dengan adanya kondisis persebaran covid-19 mencipkatan situasi yang semakin sulit untuk dihadapi dan mengatasi permasalahan sosial di tengah masyarakat. Sehingga perlu adanya kerjasama yang kuat antara pengamat dan pembuat kebijakan dalam menghadapi situasi ini.

Di lain sisi, di tengah pandemi covid-19 ini juga bisa dilihat besarnya kesadaran masyarakat untuk saling membantu satu sama lain dengan bentuk yang berbeda-beda, seperti seorang yang memberiksan bantuan kebutuhan pokok kepada lingkungan sekitar tetap tinggal, berbagi makanan untuk para pekerja harian, bergerak di jalan dan mencari masyarakat yang membutuhkan bantuan, maupun melalui penggalangan dana, seperti yang dilakukan oleh beberapa tokoh yang berpengaruh. Kondisi ini menggambarkan dipraktikannya nilai-nilai ZISWAF di tengah-tengah masyarakat secara disadari maupun tidak. Hal lain yang menjadi penting dengan adanya kondisi ini adalah pentingnya menerapkan nilai-nilai ZISWAF di tengah masyarakat sebagai bentuk dukungan pada SDGs terlebih pada saat negara, masyarakat dan dunia sedang menghadapai dampak dari pandemi covid-19. ${ }^{9}$

\section{Metode Penelitian}

Pendekatan dalam artikel ini menggunakan pendekatan kualitatif deskriptif. Jenis data yang digunakan adalah data sekunder. Data sekunder menurut Sugiyono merupakan data yang diperoleh secara tidak langsung oleh pengumpul data. Data sekunder adalah bersumber dari pihak lain atau data primer yang telah diolah sebelumnya. Data sekunder pada penulisan ini berupa data-data pendukung, baik berupa buku-buku, jurnal, atau website resmi.

Dalam pengumpulan data dilakukan dengan menggali data sekunder yang berkaitan dengan topik penelitian yang berasal dari literatur dan berita yang ada di media massa. Berbagai informasi berita yang berisi tentang perkembangan pandemi covid-19 beserta dampak dan upaya pemerintah.

Analisis data menggunakan teknik analisis deskriptif kualitatif. Penulis melakukan analisis terhadap data-data yang telah diperoleh yang kemudian disusun dengan lebih terstruktur dan disesuaikan dengan permasalahan yang sedang dikaji hingga menghasilkan gambaran dan pembahasan.

\section{Pandemi Covid-19 di Indonesia}

Virus covid-19 merupakan sebuah virus baru yang ditemukan pada akhir tahun 2019 di kota Wuhan, Tiongkok. Covid-19 tersebar melalui saluran pernafasan manusia dan persebarannya sangat cepat dan tidak dapat diprediksi hingga tersebar ke seluruh dunia dalam kurun waktu yang sangat singkat. Covid-19 menyerang saluran pernafasan manusia dan akibat terparah yang ditimbulkan adalah kematian. Di Indonesia, kasus positif pertama

\footnotetext{
${ }^{8}$ Ibid.

9 Ana Toni Roby Candra Yudha, dkk, "Instrumen Moneter Indonesia: Penentuan Arah Kebijakan", Journals of Economics Development Issues (JEDI), Volume 1, Nomor 2 (2018), 1-11.
} 
dikonfirmasi pada bulan Maret 2020, hal ini terjadi setelah terjadi kontak antara pasien dengan warga negara asing yang berasal dari Jepang. Jumlah pasien covid-19 terus meningkat dari hari ke hari dan kurva persebarannya masih belum menunjukkan akan melandai karena masih mengalami peningkatan. Sampai dengan Januari 2021, virus ini telah menyebar ke 223 negara dengan keseluruhan positif terkonfirmasi per 13 Januari 2021 berjumlah 90.054 .813 orang dan kasus meninggal 1.945 .610 orang, sedangkan di Indonesia terkonfirmasi positif 858.043 dan terkonfirmasi meninggal 24.951. Pendemi covid-19 mengubah wajah dunia dalam waktu yang sangat singkat, hanya dalam hitungan bulan pendemi ini berhasil mengubah wajah, tatanan, dan budaya baru di seluruh dunia.

Beberapa ciri yang menunjukkan bahwa seorang telah terpapar covid-91 menurut Kementrian Kesehatan Republik Indonesia yang didasarkan pada panduan yang dibuat oleh WHO. Seseorang yang telah terpapar dan terbukti positif covid-19 akan mengalami beberapa gejala, seperti demam, mengalami gangguan pada saluran pernapasan, selain itu juga positif covid-19 ditemukan pada orang yang melakukan perjalanan ke luar negeri, serta seseorang yang melakukan kontak langsung dengan pasien positf covid-19. Dalam penetapan positif covid-19 terdapat beberapa istilah, yaitu antara lain PDP (pasien dalam pantauan) merupakan seseorang yang telah melakukan pemeriksaan dan hasilnya menunjukkan positif. Sedangkan konfirmasi positif covid-19 sendiri didasarkan pada hasil uji laboratorium. Orang tanpa gejala (OTG) didefinisikan sebagai kemungkinan seseorang tertular covid-19 tanpa menunjukkan adanya gejala covid-19 dalam tubuhnya. Serta yang terakhir adalah ODP (orang dalam pantauan), yaitu orang-orang yang tidak menunjukkan gelaja namun orang tersebut telah melakukan perjananan ke luar negeri atau wilayah zona merah.

Beberapa pencegahan yang dapat dilakukan untuk menghambat atau menghentikan persebaran covid-19 adalah dengan menggunakan vaksin yang dapat meningkatkan imunitas dan mencegah terjadinya transmisi covid-19, melakukan usaha penemuan dini terhadap covid19 dan melakukan isolasi, menerapkan pola perilaku hidup bersih sehat dengan menerapkan menjaga kebersihan, cuci tangan, dan melakukan disinfektasi. Menggunakan APD bagi petugas medis ketika menangani pasien positif serta menggunakan masker jenis N95, penggunaan masker di luar rumah bagi masyarkat serta mempersiapkan daya tahan tubuh. Selain beberapa hal tersebut, persebaran covid-19 juga dapat dihambat dengan melakukan pemakaman korban covid-19 dengan menggunakan protokol kesehatan.

\section{Dampak Pandemi Covid-19 di Indonesia}

Munculnya pandemi covid-19 membawa dampak bagi seluruh aspek kehidupan manusia baik kehidupan bagi masing-masing individu maupun kehidupan secara sosial di tengah masyarakat. Berbagai dampak pandemi covid-19 antara lain dalam hal keagamaan di mana seluruh umat beragama tidak dapat melakukan ibadah secara berasama-sama, dalam dunia kesehatan banyak masyarakat yang terserang pandemi ini serta menjadi tantangan bagi petugas medis untuk melakukan penanganan terhadap pasien yang terjangkit virus dan tantangan untuk menemukan solusi berupa obat atau vaksin yang digunakan untuk menghentikan penyebaran pandemi ini, selain itu dalam hal ketahanan pangan yang mana jika aktivitas masyarakat terus menerus dihentikan akan menyebabkan tidak terpenuhinya bahan pangan atau kebutuhan pokok masyarakat karena berhentinya produksi sehingga angka 
kemiskinan akan meningkat tajam.

Dampak lain dari adanya pandemi covid-19 juga mempengaruhi aktivitas politik dan ketahanan negara. Salah satu kebijakan pemerintah dalam menghambat persebaran pandemi covid-19 adalah dengan menerapakan Pembatasan Sosial Skala Besar (PSBB), karantina wilayah, social distancing, physical distancing yang membuat masyarakat harus melakukan work from home atau bekerja dari rumah yang berakibat pada tidak maksimal produksi pangan untuk memenuhi kebutuhan pangan publik. Hal ini menjadi salah satu faktor pemerintah tidak melakukan lockdown di berbagai wilayah di Indonesia. Dalam hal sosial masyarakat sudah jelas berubah dari sebelumnya di mana adanya penerapan physical distancing dan social distancing berdampak pada perubahan perilaku masyarakat. Selain itu, pandemi covid-19 sangat berdampak pada kondisi politik dan ketahanan negara serta perekonomian di mana pada bidang ekonomi pandemi covid-19 berpengaruh terhadap pertumbuhan perkonomian, dan adanya bayang-bayang pertumbuhan ekonomi Indonesia akan mencapai titik negatif pada triwulan ketiga tahun ini.

\section{Sektor Riil}

Sektor riil dapat juga disebut real sector merupakan sektor yang sebenarnya, dalam arti sektor yang langsung bersentuhan dengan masyarakat dalam situasi perekonomian yang memiliki peran penting dan mempengaruhi atau yang keberadaannya mampu menjadi tolak ukur suatu bangsa untuk melihat pertumbuhan perekonomian. Menurut Irfan Syauqi, pertumbuhan perekonomian pasti bertumpu pada sektor riil. Dalam teorinya, sektor riil dianalogikan seperti mesin yang dapat memutar roda perekonomian bangsa. Karena sektor riil merupakan sektor yang asli dan jelas, yaitu sektor yang memberikan barang dan jasa yang dibutuhkan masyarakat dan selalu digunakan oleh masyarakat pada umumnya. Jika sektor riil di dalam suatu negara naik signifikan dan stabil, maka dapat dikatakan pertumbuhan pada negara tersebut mengalami keadaan baik. ${ }^{10}$

Sektor riil memiliki peran yang sangat penting dalam pertumbuhan perekonomian di Indonesia. Sektor riil menggambarkan bagaimana dampak luas pasar barang dan jasa menopang suatu perekonomian pada suatu negara. Suatu negara dapat dikatakan baik ketika pertumbuhan perekonomian pasar barang dan pasar uang dalam kondisi yang stabil tidak berfluktuatif. ${ }^{11}$

\section{Sustainable Development Goals (SDGs)}

Sustainable Development Goals (SDGs) atau pembangunan berkelanjutan adalah sebuah agenda yang telah disahkan pada September 2015 sekaligus sebagai kesepakatan pembangunan global pada sidang umum Perserikatan Bangsa-Bangsa (PBB). Tujuan dari Sustainable Development Goals (SDGs) adalah mengganti tujuan dari Millenium Development Goals (MDGs). SDGs memfokuskan pada tujuan tercapainya kesetaraan antar warga dan antar negara di mana SDGs ini diberlakukan bagi seluruh negara anggota PBB,

\footnotetext{
${ }^{10}$ Ina Sholati Cahyaningrum, "Pengaruh Sektor Riil dan Keuangan Syariah Terhadap Pertumbuhan Ekonomi di Indonesia Tahun 2007-2014”, An-Nisbah: Jurnal Ekonomi Syariah, Volume 4, Nomor 1 (2017), 106-128.

11 Muhammad Ali Asy'ari and Diah Wahyuningsih, "Analisis Pengaruh Sektor Moneter dan Sektor Riil Terhadap Jumlah Uang Beredar di Indonesia (Periode 2005-2012)”, Media Trend, Volume 8, Nomor 1 (2013), 42-58.
} 
baik itu negara maju, negara berkembang dan negara miskin. Pembangunan berkelanjutan ini dapat dijadikan sebagai penentu masa depan seluruh negara di dunia termasuk Indonesia.

Di dalam SDGs, terkandung prinsip yang dapat membawa sebuah perubahan yang signifikan, yakni prinsip "leave no one behind" atau tidak ada seorang pun yang ditinggalkan. Prinsip tersebut dapat diartikan bahwa capaian dari SDGs ini adalah menyelesaikan segala permasalahan masyarakat yang tertinggal. Setidaknya di dalam SDGs terdapat 17 tujuan yang pokok sudut pandangnya terletak pada persoalan ekonomi, sosial dan lingkungan di mana ketiga persoalan tersebut bersinggungan antara satu dengan yang lainnya, yaitu:

1. Mengakhiri segala bentuk kemiskinan.

2. Mengakhiri kelaparan, mencapai ketahanan pangan dan peningkatan gizi, dan mencanangkan pertanian berkelanjutan.

3. Menjamin kehidupan yang sehat dan meningkatkan penduduk di segala usia.

4. Menjamin kualitas pendidikan yang adil dan inklusif serta meningkatkan kesempatan belajar seumur hidup untuk semua.

5. Mencapai kesetaraan gender dan memberdayakan perempuan dan anak perempuan.

6. Menjamin ketersediaan dan manajemen air dan sanitasi secara berkelanjutan.

7. Menjamin akses terhadap energi yang terjangkau, dapat diandalkan, berkelanjutan dan modern.

8. Meningkatkan pertumbuhan ekonomi yang merata dan berkelanjutan, kesempatan kerja penuh dan produktif, serta pekerjaan yang layak untuk semua.

9. Membangun infrastruktur tangguh, mempromosikan industrialisasi inklusif dan berkelanjutan dan mendorong inovasi.

10. Mengurangi ketimpangan dalam dan antar negara.

11. Membuat kota dan pemukiman manusia yang adil, merata, aman, tangguh dan berkelanjutan.

12. Menjamin pola produksi dan konsumsi yang berkelanjutan.

13. Mengambil tindakan segera untuk memerangi perubahan iklim dan dampaknya.

14. Melestarikan samudera, laut, dan sumber daya kelautan secara berkelanjutan untuk pembangunan berkelanjutan.

15. Melindungi, memulihkan dan meningkatkan pemanfaatan secara berkelanjutan ekosistem darat, mengelola hutan, memerangi desertifikasi, dan menghentikan dan memulihkan degradasi lahan dan menghentikan hilangnya keragaman hayati.

16. Meningkatkan masyarakat yang inklusif dan damai untuk pembangunan berkelanjutan, menyediakan akses terhadap keadilan bagi semua dan membangun institusi yang efektif, akuntabel, dan inklusif di semua tingkatan.

17. Memperkuat sarana pelaksanaan dan merevitalisasi kemitraan global untuk pembangunan berkelanjutan.

\section{Konsep Instrumen Filantropi}

Filantropi (kedermawanan) adalah kesadaran untuk memberi dalam rangka mengatasi kesulitan dan meningkatkan kesejahteraan hidup masyarakat secara luas dalam berbagai bidang kehidupannya, yaitu dalam bidang pendidikan, ekonomi, kesehatan, tempat tinggal dan lain sebagainya. Dalam pandangan ajaran Islam, filantropi adalah perbuatan yang sangat 
mulia, bagian utama dari ketakwaan seorang muslim, perbuatan yang akan mengundang keberkahan, rahmat dan pertolongan Allah, perbuatan yang akan menyelamatkan kehidupan secara luas. Potensi filantropi umat Islam terwujud dalam bentuk zakat yang hukumnya wajib, infak, sedekah, wakaf, hibah dan derma-derma lainnya.

Definisi zakat dari segi Bahasa adalah suci, berkah dan berkembang. Menurut istilah, zakat adalah nama bagi sejumlah harta tertentu yang diwajibkan oleh Allah untuk dikeluarkan dan diberikan kepada yang berhak menerimanya dengan persyaratan tertentu pula.

Infak berarti mengeluarkan sesuatu (harta) untuk kepentingan sesuatu. Sedangkan menurut terminologi syariat, infak berarti mengeluarkan sebagian dari harta atau pendapatan atau penghasilan untuk suatu kepentingan yang diperintahkan ajaran Islam. Infak digunakan untuk dapat mengeluarkan sebagian kecil harta untuk kemaslahatan umum dan berarti sesuatu kewajiban yang dikeluarkan atas keputusan manusia.

Sedekah merupakan wujud dari keimanan dan ketakwaan seseorang. Artinya, orang yang suka bersedekah adalah orang yang benar pengakuan imannya. Dalam istilah syariat Islam, sedekah sama dengan pengertian infak termasuk juga hukum dan ketentuanketentuannya. Sisi perbedaan hanya terletak pada bendanya, artinya infak berkaitan dengan materi sedangkan sedekah berkaitan dengan materi dan non materi baik dalam bentuk pemberian benda atau uang, tenaga atau jasa, menahan diri untuk tidak berbuat kejahatan, bahkan yang paling sederhana adalah tersenyum kepada orang lain dengan ikhlas. Dengan demikian dapat dipahami bahwa sedekah adalah keseluruhan amal kebaikan yang dilakukan umat muslim untuk menciptakan kesejahteraan umat manusia, termasuk untuk kelestarian lingkungan hidup dan alam semesta.

\section{Dampak Pandemi Covid-19 dan Solusi Alternatif dalam Menjaga Ketahanan Sektor Riil di Tengah Pandemi}

Pandemi covid-19 merupakan jenis virus baru yang menyerang saluran pernafasan dan menyebabkan gangguan pernafasan dan bahkan kematian. Keputusan Presiden Republik Indonesia Nomor 12 Tahun 2020 menetapkan Corona Virus Disease 2019 sebagai bencana nasional non alam. Persebaran covid-19 per 13 Januari 2021 berjumlah 90.054 .813 orang positif, dan 1.945 .610 orang meninggal diseluruh dunia, dan 858.043 orang positif dan 24.951 orang terkonfirmasi meninggal di Indonesia. Pemerintah menerapkan kebijakan untuk menghentikan laju persebaran covoid-19 melalui beberapa kebijakan seperti lockdown, social distancing, dan WFO (work from home). Beberapa faktor yang menghambat penanganan pandemi covid-19 di antaranya adalah virus covid-19 merupakan virus baru sehingga diperlukan adanya penemuan vaksin yang pembuatannya membutuhkan waktu yang lama; sumber daya manusia, faktor ini berkaitan dengan kemampuan sumber daya tenaga medis, pemerintah maupun pembuat kebijakan dan masayarakat dalam menghadapi pandemi covid19; dan sarana prasarana.

Selain itu, pandemi covid-19 juga berdampak pada jenis pajak lain, di antaranya pada pajak impor terjadi kontraksi sebesar 8,51 persen year on year dan pada PPN impor terjadi kontrasi sebesar 8,72 persen year on year. Berdasarkan data dari Badan Pusat Statistik (BPS) merilis secara keseluruhan nilai impor Indonesia pada triwulan pertama khusunya bulan Januari sampai dengan bulan Februari terjadi kontraksi sebesar 4,95 persen year on year. Pada industri pengelolaan terjadi pertumbuhan sebesar 5,97 persen, sektor perdagangan 
pertumbuhannya menuju arah negatif mencapi $-1,33$ persen, jasa keuangan dan asuransi mengalami kontraksi dari tahun sebelumnya sebesar 11,06 persen menjadi 2,67 persen, dan sektor transportasi dan pergudangan mengalami kontraksi dari yang semula 24,87 persen menjadi 0,87 persen.

Menteri Keuangan Sri Mulyani menyampaikan bahwa tantangan terberat yang akan terjadi pada pertumbuhan ekonomi Indonesia yang akan mencapi 0,4 prsen yang disebabkan karena adanya penurunan konsumsi rumah tangga dan investasi. Hal ini akan mengancam stabilitas perekonomian Indonesia. Beberapa proyeksi pertumbuhan ekonomi Indonesia yang disampaikan oleh Kementerian Keuangan pada tahun 2021, pertumbuhan ekonomi akan berada pada angka 4,5 persen hingga 5,5 persen, Bank Indonesia memproyeksikan pertumbuhan ekonomi pada kisaran 6,6 hingga 7,1 persen yang dipengaruhi oleh stimulus fiskal yang dilakukan oleh pemerintah serta ditopang dari program restrukturisasi kredit, serta penundaan ekspanis moneter Bank Indonesia. Sedangkan IMF Memproyeksikan pertumbuhan ekonomi Indonesia berada pada angka 8,2 persen.

Dampak lain dari adanya pendemi covid-19 adalah tumbuhnya angka kemiskinan. Berdasakan data yang dikutip dari CNBC, peningkatan angka kemiskinan sebagai akibat dari adanya pandemi covid-19 diprediksi akan mencapi angka 49 juta orang di seluruh dunia dan di Indonesia diperkirakan angka kemiskinan akan meningkat. Data dari CORE (Centre of Reform on Economics) angka kemiskinan akan meningkat pada skala berat sebanyak 5,1 juta orang dan 8,25 juta orang pada skala lebih berat dan dalam kategori sangat berat pertambahan penduduk miskin mencapi 12,2 juta orang. Peningkatan jumlah kemiskinan karena banyak masyarakat yang kehilangan pekerjaan dan tidak berpenghasilan serta kemampuan pemerintah yang terbatas. Tingginya angka pemutusan hubungan kerja (PHK) berdampak pada banyaknya masyarakat yang tidak memiliki penghasilan, oleh karenanya angka kemiskinan bertambah. Selain berdampak pada meningkatnya angka kemiskinan pandemi juga berdampak pada daya beli atau konsumsi masyarakat yang menurun.

Meningkatnya angka kemiskinan dan menurunnya tingat konsumsi masyarakat serta penerimaan negara yang menurun sangat berdampak besar bagi perekonomian nasioanl. Hal ini juga dipengaruhi oleh perekonian secara global di mana perekonomian dunia masih mengalami kekacauan akibat pandemi covid-19. Oleh karena itu, setiap kebijakan yang dipilih pemerintah menjadi sesuatu yang samar yang memberikan dua kemungkinan, yaitu kemungkinan untuk memperbaiki atau justru kemungkinan kondisi semakin memburuk. Hal ini terjadi ketika kebijakan yang pemerintah terapkan tidak sesuai dengan keadaan di lapangan. Kondisi masayarakat dan pertumbuhan ekonomi negara sepenuhnya ada di tangan pemerintah serta adanya kerjasama dan dukungan masyarakat untuk menghentikan laju persebaran pandemi covid-19 menjadi sangat penting.

Pemerintah dan seluruh elemen telah menerapkan sejumlah kebijakan yang terkait sejauh ini telah menerapkan himbauan dan kebijakan dalam mengantisipasi penyebaran virus dan masih terus memikirkan penanggulangan yang tepat untuk menghentikan penyebaran covid-19. Hal itu jelas upaya solutif yang dilakukan oleh pemerintah yang juga dibantu oleh sejumlah pemangku kepentingan lain, seperti swasta, industri dan tentunya masyarakat. Pemerintah telah melakukan realokasi anggaran untuk ditambahkan kepada penanganan covid-19 baik bagi aspek kesehatan, pemulihan ekonomi, serta jaminan sosial. Secara umum, 
prioritas utama pemerintah saat ini adalah memberi dukungan penuh untuk sektor kesehatan, menguatkan jaringan pengamanan sosial, dan menyelamatkan sektor dunia usaha.

\section{Strategi Penyusunan Kebijakan dalam Rangka Menjaga Kestabilan Ekonomi Mikro dan Meminimalisir Terjadinya Resesi Ekonomi.}

Sebagaimana ulasan sebelumnya bahwa sektor ekonomi mikro yang sangat terdampak dari pandemi covid-19. Maka perlu disampaikan pula tentang strategi penyusunan kebijakan menjaga kestabilan ekonomi mikro dan memimalisir terjadinya resesi ekonomi. Hal ini jika dikatakan lebih kepada model alternatif pemulihan ekonomi mikro pun tidak sepenuhnya salah, karena kecenderungan kontribusi yang disampaikan adalah pada pemulihan sektor ekonomi mikro tanpa mengesampingkan bidang lain, seperti aspek kesehatan, pariwisata, pendidikan dan aspek lain yang juga perlu dipulihkan. Berikut model yang dapat dijadikan referensi dalam penyusunan kebijakan.

Gambar 1.1. Skema Prioritas Kebijakan Penanganan Pandemi Covid-19

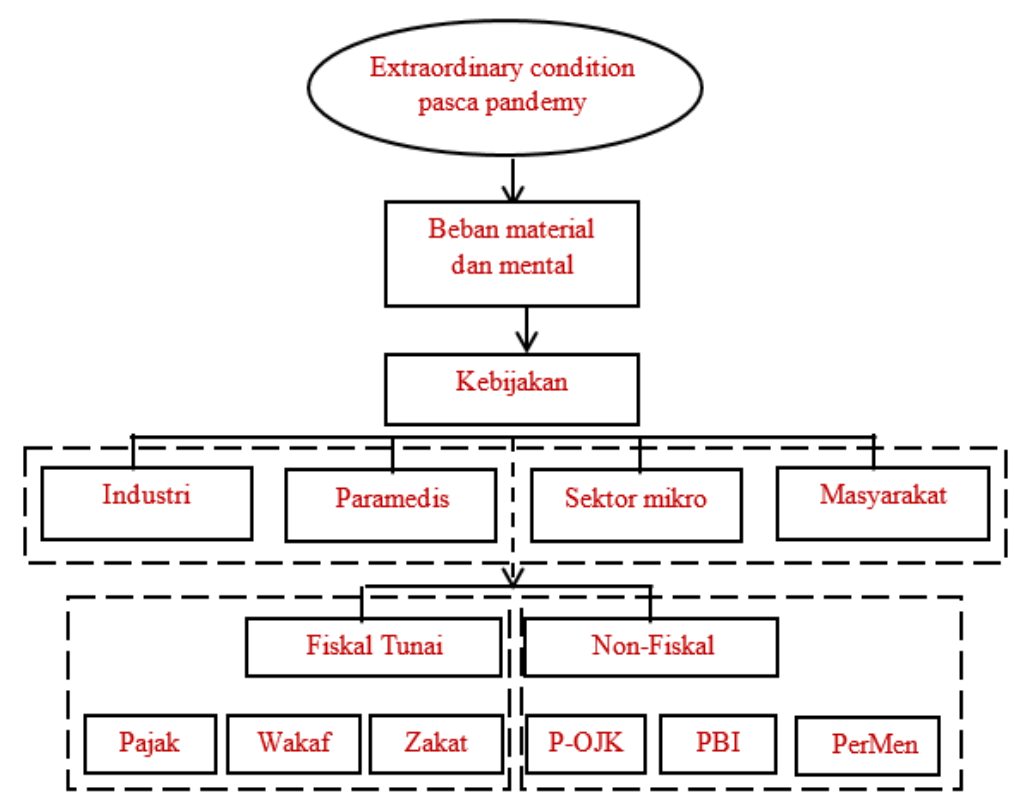

Bersesuaian dengan ulasan pada bagian sebelumnya serta diperjelas dengan gambar 1.1., maka dapat dipetakan serta diketahui sekaligus skala prioritas yang sebaiknya didahulukan dalam melahirkan kebijakan. Pengaruh yang berat dirasakan di bidang kesehatan dan sejumlah sektor lain, pemerintah sudah menyediakan sejumlah peralatan untuk tenaga medis seperti APD, kemudian pemerintah juga telah membuat rumah sakit darurat yang memadai bagi pasien positif covid-19. Selanjutnya, dalam menguatkan jaring pengaman sosial untuk membantu perekonomian, pemerintah mewujudkannya dalam beberapa bentuk, di antaranya adalah bantuan langsung tunai (BLT) sebesar Rp. 600.000,- untuk setiap kepala keluarga, kemudian dikeluarkannya program kartu pra-kerja yang diperuntukkan bagi masyarakat yang belum memiliki pekerjaan dan bagi masyarakat yang menjadi korban PHK, serta adanya kebijakan penangguhan angsuran.

Kebijakan lain yang diterapkan pemerintah yang tertuang dalam Perppu Nomor 1/2020 adalah kebijakan pajak dengan menurunkan tarif PPh Badan secara bertahap, perlakuan pajak kegiatan perdagangan melaui sistem elektronik, serta perpanjangan waktu pengajuan wajib 
pajak dan penyelesaian oleh DJP. Kemudian kebijakan stimulus dalam menangani dampak pandemi covid-19 serta adanya kebijakan transfer ke daerah dana-dana desa dengan tujuan pencegahan dan penanganan covid-19.

Kebijakan pemerintah sangat layak untuk diapresiasi karena setiap bantuan telah diarahkan secara langsung kepada pihak-pihak terdampak covid-19. Kebijakan yang diterapkan juga sejalan dengan tujuan SDGs tujuan pertama, yaitu mengakhiri kemiskinan dalam segala bentuk di manapun, ${ }^{12}$ tujuan kedelapan terkait dukungan terhadap pertumbuhan ekonomi yang inklusif dan berkelanjutan, tenaga kerja penuh dan produktif dan pekerjaan yang layak bagi semua, serta tujuan kesepuluh, yakni tujuan untuk mengurangi ketimpangan di dalam dan antar negara.

Namun pada praktiknya sampai saat ini hal tersebut tidak memberikan hasil yang signifikan terhadap pertumbuhan ekonomi. Salah satu penyebabnya adalah anggaran pemerintah tidak sebanding dengan banyaknya jumlah masyarakat dan pendistribusiannya juga kurang merata. Satu-satunya cara yang dapat meningkatkan perekonomian adalah bahwa orang kaya dan pemerintah dapat bersatu dan bergandengan tangan untuk membantu masyarakat yang kekurangan.

Indonesia dengan jumlah penduduk muslim yang cukup banyak dapat menjadi solusi dalam menghadapi permasalahan ekonomi yang disebabkan oleh pandemi covid-19. Dengan melalui instrumen filantropi Islam dalam bentuk pemungutan dan penyaluran zakat, infak, dan sedekah.

\section{Kesimpulan}

Dari pembahasan di atas, maka ada dua hal penting yang bisa disimpulkan, yaitu pertama, solusi alternatif dalam menjaga ketahanan sektor riil di tengah pandemi baik pemerintah, masyarakat serta seluruh elemen telah menerapkan sejumlah kebijakan dengan mengikuti protokol kesehatan dan kebijakan dalam menghentikan penyebaran covid-19. Pemerintah telah melakukan relokasi anggaran untuk digunakan dalam penanganan covid-19 baik bagi aspek kesehatan, pemulihan ekonomi, serta jaminan sosial. Secara umum, prioritas utama pemerintah saat ini adalah memberi dukungan penuh untuk sektor kesehatan, menguatkan jaringan pengamanan sosial, dan menyelamatkan sektor dunia usaha.

Kedua, strategi penyusunan kebijakan dalam rangka menjaga kestabilan ekonomi mikro dan meminimalisir terjadinya resesi ekonomi dapat dilihat dari skala prioritas yang sebaiknya didahulukan dalam melahirkan kebijakan. Pengamanan di bidang kesehatan dan selanjutnya menguatkan jaring pengaman sosial untuk membantu perekonomian.

\section{Daftar Rujukan}

Abdullah, Mohammad. "Waqf, Sustainable Development Goals (SDGs) and Maqasid AlShariah", International Journal of Social Economics, Volume 45, Nomor 1 (2018).

Asy'ari, Muhammad Ali dan Diah Wahyuningsih. "Analisis Pengaruh Sektor Moneter dan

Sektor Riil Terhadap Jumlah Uang Beredar di Indonesia (Periode 2005-2012)", Media

Trend, Volume 8, Nomor 1 (2013).

Atkeson, Andrew, "What Will Be the Economic Impact of Covid-19 in the US? Rough

${ }^{12}$ Mohammad Abdullah, "Waqf, Sustainable Development Goals (SDGs)", 158-172. 
Estimates of Disease Scenarios," NBER Working Paper Series (2020).

Cahyaningrum, Ina Sholati. "Pengaruh Sektor Riil dan Keuangan Syariah Terhadap Pertumbuhan Ekonomi di Indonesia Tahun 2007-2014”, An-Nisbah: Jurnal Ekonomi Syariah, Volume 4, Nomor 1 (2017).

Fernandes, Nuno. "Economic Effects of Corona Virus Outbreak (Covid-19) on the World Economy", SSRN Electronic Journal, Volume 13, Nomor 1 (2020).

Santoso, Priyono Budi, dkk. "Studi Eksploratif Dampak Pandemi Covid-19 Terhadap Proses

Pembelajaran Online di Sekolah Dasar", Journal of Education, Psycology, and Counseling, Volume 2, Nomor 1 (2020).

Vega, Danny Ibarra. "Lockdown, One, Two, None, or Smart. Modeling Containing Covid-19 Infection. A Conceptual Model”, Science of The Total Environment, Volume 16, Nomor 2 (2020).

Yudha, Ana Toni Roby Candra, dkk. "Instrumen Moneter Indonesia: Penentuan Arah Kebijakan", Journals of Economics Development Issues (JEDI), Volume 1, Nomor 2 (2018).

. "The Synergy Model for Strengthening the Productivity of Indonesian Halal Industry", Al-Uqud, Volume 4, Nomor 2 (2020).

Zaki, Irham, dkk. "Implementation of Islamic Entrepreneurial Culture in Islamic Boarding Schools", International Journal of Innovation, Creativity and Change, Volume 11, Nomor 11 (2020). 